\title{
PENERAPAN MEDIA PEMBELAJARAN LKS MODEL INKUIRI \\ UNTUK MENINGKATKAN MOTIVASI BELAJAR SISWA \\ PADA MATA PELAJARAN IPS
}

\author{
Ahmad Muzaki ${ }^{1}$, Cecep Sumarna ${ }^{2}$ \\ IAIN SyekhNurjati Cirebon 1,2 \\ ahmadmuzaki@syekhnurjati.ac.id;cecepsumarna@syekhnurjati.ac.id
}

\begin{abstract}
ABSTRAK
Tujuan penelitian ini adalah untuk meningkatkan motivasi belajar siswa pada mata pelajaran IPS sedangkan secara khusus penelitian ini bertujuan untuk mendeskripsikan penerapan media LKS menggunakan model pembelajaran Inkuiri di kelas VIII B SMP Muhammadiyah 01 Sirampog Kabupaten Brebes. Penelitian ini bertolak dari pemikiran bahwa siswa belum memiliki media pembelajaran yang mandiri sehingga mengalami kesulitan dalam mencari sumber belajar sehingga diharapkan dengan diterapkannya media pembelajaran LKS yang bersifat mandiri dikemas dengan model pembelajaran Inkuiri dan secara tidak langsung siswa memiliki tanggung jawab masing-masing maka diharapkan motivasi belajar siswa meningkat.

Penelitian ini merupakan Penelitian Tindakan Kelas (PTK). Subjek penelitian adalah siswa kelas VIII B SMP Muhammadiyah 01 Sirampog Kabupaten Brebes Adapun teknik pengumpulan datanya menggunakan observasi dan tes, serta instrumennya berupa lembar pengamatan dan soal tes.

Hasil penelitian menunjukan adanya peningkatan motivasi dan hasil belajar siswa berdasarkan hasil pengamatan motivasi belajar siswa pada siklus 1 sebesar $52 \%$ kemudian siklus 2 sebesar $72,5 \%$ dan siklus 3 sebesar $90 \%$. Sedangkan hasil belajar siswa pra siklus diperoleh nilai rata-rata 58,06 dengan persentase ketuntasan belajar siswa sebesar $36 \%$ atau hanya 12 siswa yang tuntas. Setelah dilaksanakannya siklus 1 diperoleh nilai rata-rata 64,09 dengan persentase ketuntasan belajar 54\% atau 20 siswa yang tuntas, selanjutnya siklus 2 diperoleh nilai rata-rata kelas 70,15 dengan persentase $69 \%$ atau 23 siswa tuntas dan siklus 3 diperoleh nilai rata-rata kelas 82,69 dengan presentase 93\% atau 31 siswa tuntas dari 33 siswa. Dengan demikian dapat disimpulkan penerapan media LKS model Inkuiri dapat meningkatkan motivasi belajar siswa.
\end{abstract}

Kata kunci: PersepsiSiswa, PolaInteraksiSosial, Pembelajaran IPS.

\begin{abstract}
The purpose of this study was to improve student learning motivation in social studies subjects while specifically this study aimed to describe the application of LKS media using Inquiry learning models in class VIII B Muhammadiyah Middle School 01 Sirampog Brebes Regency. This research departs from the idea that students do not yet have independent learning media so that they have difficulty in finding learning resources so that it is expected that the
\end{abstract}


application of independent LKS learning media will be packaged with Inquiry learning models and indirectly students have their respective responsibilities. students increase.

This study is a Classroom Action Research (CAR). The research subjects were class VIII B Muhammadiyah Middle School 01 Sirampog Brebes Regency The data collection techniques used observation and tests, and the instruments were observation sheets and test questions.

The results showed an increase in motivation and student learning outcomes based on observations of student learning motivation in the first cycle of $52 \%$ then cycle 2 by $72.5 \%$ and cycle 3 by $90 \%$. While the pre-cycle student learning outcomes obtained an average value of 58.06 with the percentage of student learning completeness by $36 \%$ or only 12 students who completed. After the first cycle, the average value of 64.09 was obtained with the percentage of learning completeness $54 \%$ or 20 students completed, then the second cycle obtained the average grade of 70.15 with a percentage of $69 \%$ or 23 students completed and cycle 3 obtained an average value -grade average of 82.69 with a percentage of $93 \%$ or 31 students completing from 33 students. Thus it can be concluded that the application of LKS media inquiry model can increase student learning motivation.

Keywords: Learning Media, LKS Media, Inquiry Model, Student Learning Motivation.

\section{A. Pendahuluan}

\section{LatarBelakangMasalah}

Proses belajar merupakan aktivitas yang sangat penting, karena dengan melalui proses itulah tujuan pendidikan akan dapat dicapai dalam bentuk perubahan perilaku atau pribadi siswa. Undang-undang Nomor 20 tahun 2003 tentang Sistem Pendidikan Nasional pasal 3, menjelaskan fungsi pendidikan nasional adalah mengembangkan kemampuan dan membentuk watak serta peradaban bangsa yang bermartabat dalam rangka mencerdaskan kehidupan bangsa dan tujuan pendidikan nasional untuk mengembangkan potensi peserta didik agar menjadi manusia yang beriman dan bertaqwa kepada Tuhan Yang Maha Esa, berakhlak mulia, sehat, berilmu, cakap, kreatif, mandiri, dan menjadi warga Negara yang demokratis serta bertanggung jawab (Susanti Aryani, 2010: 12).

Pendidikan selalu mengalami pembaharuan dalam rangka mencari struktur kurikulum sistem pendidikan dan metode pengajaran yang efektif dan efisien dalam pembelajaran IPS di sekolah. Upaya tersebut antara lain 
peningkatan sarana dan prasarana, peningkatan mutu para pendidik dan peserta didik serta perubahan dan perbaikan kurikulum.

Menurut hasil observasi yang dilakukan peneliti di SMP Muhammadiyah 01 Sirampog yang terletak di Jalan Raya Pasar Sirampog, Desa Mendala Kecamatan Sirampog, Kabupaten Brebes, Provinsi Jawa Tengah. Pada kelas VIII B terdapat 33 siswa yang terdiri dari 16 siswa laki-laki dan 17 siswi perempuan, diketahui bahwa siswa belum memiliki bahan belajar mandiri seperti buku cetak, LKS maupun modul, selain hanya mengandalkan buku catatan yang mereka catat. Adapun buku cetak yang tersedia di perpustakaan sekolah jumlahnya sangat terbatas sehingga satu buku tersebut hanya dapat digunakan oleh 3-4 siswa. Hal itu ditambah dengan gaya mengajar guru yang konvensional yaitu mengandalkan metode ceramah dan penugasan sehingga membuat pembelajaran tidak maksimal. Akhirnya ketika ulangan harian maupun ujian tengah semester (UTS), tidak sedikit dari siswa yang mendapatkan nilai di bawah kriteria ketuntasan minimum (KKM).

Berdasarkan pertimbangan di atas, maka perlu dikembangkan suatu media dan model pembelajaran yang mampu melibatkan peran serta siswa secara menyeluruh sehingga kegiatan belajar mengajar tidak hanya didominasi oleh siswa-siswa tertentu saja. Selain itu, melalui pemilihan media dan model pembelajaran tersebut diharapkan sumber informasi yang diterima siswa tidak hanya dari guru tetapi juga dapat meningkatkan peran serta keaktifan dan motivasi belajar siswa dalam mempelajari dan menelaah ilmu yang ada terutama mata pelajaran IPS.

Berdasarkan latar belakang masalah di atas maka dirumuskan judul penelitian sebagai berikut: "PENERAPAN MEDIA PEMBELAJARAN LKS MODEL INKUIRI UNTUK MENINGKATKAN MOTIVASI BELAJAR SISWA PADA MATA PELAJARAN IPS KELAS VIII DI SMP MUHAMMADIYAH O1 SIRAMPOG KABUPATEN BREBES". 


\section{RumusanMasalah}

Berdasarkan identifikasi masalah dan pembatasan masalah yang telah dikemukakan di atas, maka dapat dirumuskan beberapa permasalahan sebagai berikut:

a. Bagaimana Penerapan Media lembarkerjasiswa (LKS) Model Inkuiridalammatapelajaran IPS kelas VIII di SMP Muhammadiyah 01 Sirampog Kabupaten Brebes?

b. Bagaimanamotivasi belajar siswa setelah Penerapan Media lembarkerjasiswa (LKS) Model Inkuiridalammatapelajaran IPS kelas VIII diSMP Muhammadiyah 01 Sirampog Kabupaten Brebes?

c. Bagaimana hasil belajar siswasetelah penerapan Media lembarkerjasiswa (LKS) Model Inkuiridalammatapelajaran IPS kelas VIII diSMP Muhammadiyah 01 Sirampog Kabupaten Brebes?

\section{TujuanPenelitian}

Berdasarkan permasalahan yang ada maka penelitian ini bertujuan untuk:

a. Mengetahui penerapan Media lembar kerja siswa (LKS) Model Inkuiri dalam mata pelajaran IPS kelas VIII di SMP Muhammadiyah 01 Sirampog Kabupaten Brebes.

b. Mengetahui motivasi belajar siswa setelah penerapan Media lembar kerja siswa (LKS) Model Inkuiri dalam mata pelajaran IPS kelas VIII diSMP Muhammadiyah 01 Sirampog Kabupaten Brebes.

c. Mengetahui hasil belajar siswa setelah penerapan Media lembar kerja siswa (LKS) Model Inkuiri dalam mata pelajaran IPS kelas VIII di SMP Muhammadiyah 01 Sirampog Kabupaten Brebes.

\section{B. Kajian Teori}

1. Pengertian Media Pembelajaran LKS

Lembar Kerja Siswa (LKS) menurut Indrianto dalam Alan (2012: 89) adalah lembar kerja siswa yang berisi pedoman bagi siswa untuk melakukan kegiatan yang mencerminkan ketrampilan proses agar siswa memperoleh pengetahuan atau ketrampilan yang perlu dikuasainya. Lembar Kerja Siswa (LKS) adalah lembaran-lembaran berisi tugas yang harus dikerjakan oleh 
siswa. LKS biasanya berupa petunjuk, langkah-langkah untuk menyelesaikan suatu tugas. Suatu tugas yang diperintahkan dalam lembar kegiatan harus jelas kaitannya dengan kompetensi yang akandi capai.

2. Pengertian Model Pembelajaran Inkuiri

Model Pembelajaran Inkuiri adalah rangkaian kegiatan pembelajaran yang menekankan pada proses berpikir secara kritis dan analis untuk mencari dan menemukan sendiri jawaban dari suatu masalah yang dipertanyakan, Proses berpikir itu biasanya dilakukan melalui tanya jawab antara guru dan siswa (Sanjaya 2010: 196). Kemudian menurut Komalasari (2011: 73) menyatakan bahwa:

Model pembelajaran inkuiri adalah model pembelajaran yang berupaya menanamkan dasar-dasar berpikir ilmiah pada diri siswa, sehingga dalam proses pembelajaran ini siswa lebih banyak belajar sendiri, mengembangkan kreativitas dan memahami konsep dan memecahkan masalah.

3. Pengertian Motivasi Belajar

Menurut Hamzah B. Uno (2012: 3) motivasi adalah dorongan yang terdapat dalam diri sesorang untuk berusaha mengadakan perubahan tingkah laku yang lebih baik dalam memenuhi kebutuhannya. Sedangkan Sardiman (2012: 75) berpendapat bahwa motivasi dapat juga dikatakan serangkaian usaha untuk menyediakan kondisi-kondisi tertentu, sehingga seseorang mau dan ingin melakukan sesuatu.

\section{Metode Penelitian}

\section{Jenis Penelitian}

Jenis penelitian yang dilaksanakan oleh peneliti adalah Penelitian Tindakan Kelas atau Classroom Action Research (CAR). Arikanto (2015: 4) menyatakan pendekatan penelitian yang sering kali digunakan dalam PTK adalah pendekatan kuantitatif dan kualitatif, sebab dalam melakukan tindakan kepada subjek penelitian, yang sangat diutamakan adalah mengungkapkan makna, yakni makna dan proses pembelajaran sebagai upaya meningkatkan motivasi, kegairahan dan prestasi belajar melalui tindakan yang dilakukan. 
Di dalam penelitian ini, kegiatan peneliti di lapangan adalah untuk menyusun rencana kegiatan, melaksanakan tindakan pembelajaran, mengadakan evaluasi dan akhirnya melaporkan hasil penelitian.

2. Lokasi dan Waktu Penelitian

Penelitian tindakan kelas ini dilakukan di kelas VIII B SMP Muhammadiyah 01 Sirampog Kecamatan Sirampog Kabupaten Brebes Privinsi Jawa Tengah. Adapun waktu pelaksanaan penelitian daribulanMaret 2018 - Mei 2018.

\section{SubjekPenelitian}

Subjek dalam penelitian ini adalah siswa kelas VIIIB SMP Muhammadiyah 01 Sirampog sebanyak 33 anak dengan komposisi 16 siswa laki-laki dan 17 siswi perempuan.

\section{Instrumen Pengumpulan Data}

Instrumen pengumpulan data merupakan alat yang digunakan dalam sebuah penelitian untuk mengambil data yang dibutuhkan dan sebagai penunjang dalam melakukan teknik pengumpulan data. Dalam penelitian ini menggunakan instrumen pengumpulan data berupa tes dan lembar observasi.

a. Tes berupa pertanyaan menggunakan instrumen soal berupa pilihan ganda untuk mengukur hasil belajar yang dilakukan setiap akhir pembelajaran.

b. Lembar observasi berupa lembar pengamatan yang terdiri lembar pengamatan motivasi belajar untuk siswa dan aktivitas mengajar guru, lembar pengamatan ini untuk mengukur motivasi belajar siswa dan aktivitas mengajar guru saat pembelajaran berlangsung.

\section{Hasil Penelitian dan Pembahasan}

1. Prosedur Penelitian

Sebelum melakukan penelitian tindakan kelas, peneliti melakukan observasi terlebih dahulu untuk mengetahui secara benar dan pasti masalah yang terjadi dalam pembelajaran Ilmu Pengetahuan Sosial (IPS) di kelas VIII, observasi sebenarnya telah dilakukan sejak dulu, karena peneliti merupakan alumni dari SMP Muhammadiyah 01 Sirampog, dulu peneliti mengalami kesulitan dalam proses belajar-mengajar karena bahan ajar berupa buku yang 
tersedia di sekolah tersebut sangat minim khususnya mata pelajaran IPS dan siswa belum mempunyai media pembelajaran bersifat mandiri seperti LKS ataupun modul yang hal itu berimbas pada hasil belajar yang rendah dan cenderung tidak melampaui kriteria ketuntasan belajar (KKM) sebesar 60 .

Berdasarkan hal tersebut peneliti menemui guru mata pelajaran IPS pada tanggal 21 April 2018, dalam pertemuan tersebut peneliti menanyakan beberapa hal mengenai, media pembelajaran mata pelajaran IPS yang tersedia untuk siswa, metode dan model pembelajaran yang digunakan dalam mengajar pembelajaran IPS dan hasil belajar siswa kelas VIII. Dalam pertemuan tersebut guru mata pelajaran IPS mengatakan media pembelajaran yang tersedia dalam sekolah ini untuk sementara hanya buku perpustakaan, siswa belum mempunyai bahan belajar mandiri seperti LKS ataupun modul kemudian dalam proses belajar-mengajar masih menggunakan metode ceramah, mencatat dan penugasan individu maupun kelompok. Selanjutnya hasil belajar siswa kelas VIII cenderung rendah dan mayoritas belum tercapai terhadap kriteria ketuntasan minimum yang ditetapkan sekolah sebesar 60 .

Peneliti tergerak dan termotivasi untuk melakukan penelitian tindakan kelas dengan menerapkan media pembelajaran LKS menggunakan model pembelajaran Inkuiri untuk meningkatkan motivasi belajar serta hasil belajar siswa. Peneliti dianjurkan untuk melakukan tindakan di kelas VIII B dikarenakan menurut guru mata pelajaran IPS, Kelas VIII B cenderung memiliki nilai rata-rata kelas yang rendah dan persentase keaktifan belajar yang cenderung rendah.

2. Hasil Motivasi Belajar Siswa dan Hasil Aktivitas Mengajar guru Dengan Menerapkan Media LKS Menggunakan Model Pembelajaran Inkuiri

Motivasi belajar siswa kelas VIII B SMP Muhammadiyah 01 Sirampog Kab. Brebes dengan menerapkan media LKS menggunakan model pembelajaran Inkuiri mengalami peningkatan disetiap siklusnya dan telah melampaui indikator yang telah ditetapkan sebesar $75 \%$ sehingga dinyatakan dapat meningkatkan motivasi belajar siswa pada mata pelajaran IPS. 
Tabel 1

Peningkatan Motivasi Belajar Siswa

\begin{tabular}{|c|c|c|c|}
\hline No. & Kegiatan & Persentase & Kategori \\
\hline 1 & Siklus 1 & $52 \%$ & Aktif \\
\hline 2 & Siklus 2 & $\mathbf{7 2 , 5 \%}$ & Aktif \\
\hline 3 & Siklus 3 & $\mathbf{9 0 \%}$ & Sangat Aktif \\
\hline
\end{tabular}

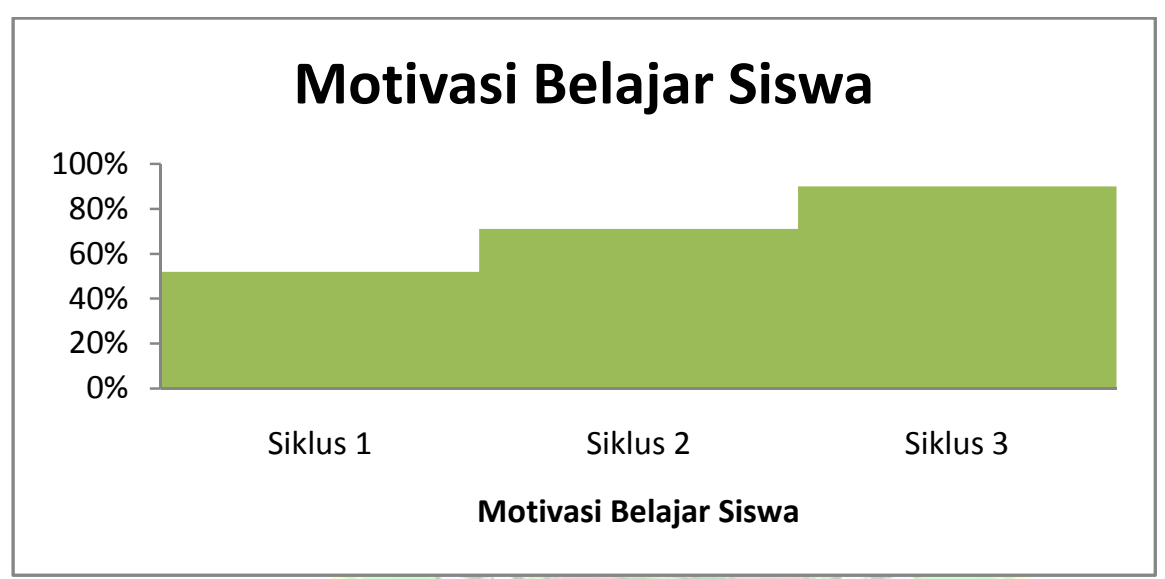

Gambar 1. Grafik Peningkatan Motivasi Belajar Siswa

Berdasarkan grafik motivasi belajar siswa di atas menunjukan adanya peningkatan yaitu pada siklus 1 mengalami peningkatan dari 52\% menjadi $72,5 \%$ pada siklus 2 dan $90 \%$ pada siklus 3 dengan kategori sangat aktif.

Tabel 2

Peningakatan Aktivitas Mengajar Guru

\begin{tabular}{|c|c|c|c|}
\hline No. & Kegiatan & Persentase & Kategori \\
\hline 1 & Siklus 1 & $\mathbf{5 0 \%}$ & Baik \\
\hline 2 & Siklus 2 & $\mathbf{7 1 \%}$ & Baik \\
\hline 3 & Siklus 3 & $\mathbf{8 1 \%}$ & Sangat Baik \\
\hline
\end{tabular}




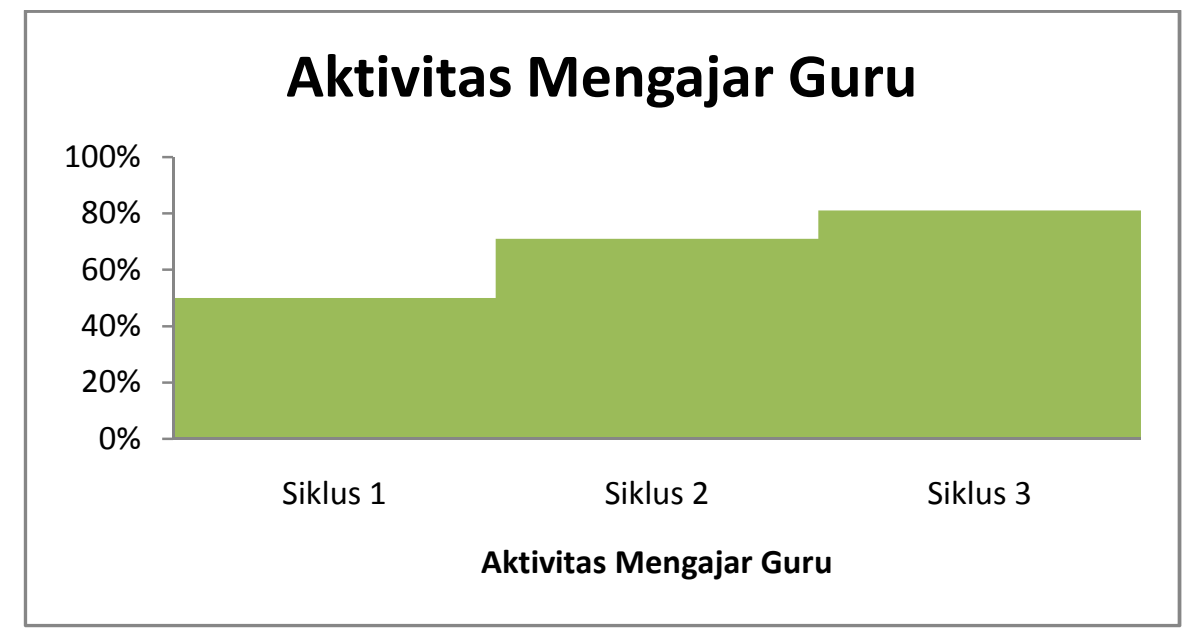

Gambar 2. Grafik Peningkatan Mengajar Guru

Berdasarkan grafik aktivitas mengajar guru di atas menunjukan adanya peningkatan yaitu pada siklus 1 mengalami peningkatan dari $50 \%$ menjadi $71 \%$ pada siklus 2 dan $81 \%$ pada siklus 3 dengan kategori sangat baik.

3. Hasil Belajar Siswa Dengan Menerapkan Media LKS Model Inkuiri

Hasil belajar siswa kelas VIII B SMP Muhammadiyah 01 Sirampog Kab. Brebes dengan menerapkan media LKS model Inkuiri mengalami peningkatan di setiap siklusnya. Hasilnya telah melampaui indikator keberhasilan yang telah ditetapkan sebesar $75 \%$ sehingga dinyatakan dapat meningkatkan hasil belajar siswa kelas VIII B SMP Muhammadiyah 01 Sirampog Kab. Brebes.

Tabel 3

Hasil belajar siswa

\begin{tabular}{|c|c|c|c|c|c|}
\hline Aspek & Pra Siklus & Siklus 1 & Siklus 2 & Siklus 3 & Kategori \\
\hline $\begin{array}{c}\text { Rata-rata } \\
\text { Kelas }\end{array}$ & 58,06 & 64,09 & 70,15 & 82,69 & Meningkat \\
\hline $\begin{array}{c}\text { Ketuntasan } \\
\text { Belajar }\end{array}$ & $\begin{array}{c}36 \% \\
\text { (12 Siswa } \\
\text { Tuntas) }\end{array}$ & $\begin{array}{c}54 \% \\
\text { (20 Siswa } \\
\text { Tuntas) }\end{array}$ & $\begin{array}{c}69 \% \\
\text { (23 Siswa } \\
\text { Tuntas) }\end{array}$ & $\begin{array}{c}93 \% \\
\text { (31 Siswa } \\
\text { Tuntas) }\end{array}$ & Meningkat \\
\hline
\end{tabular}




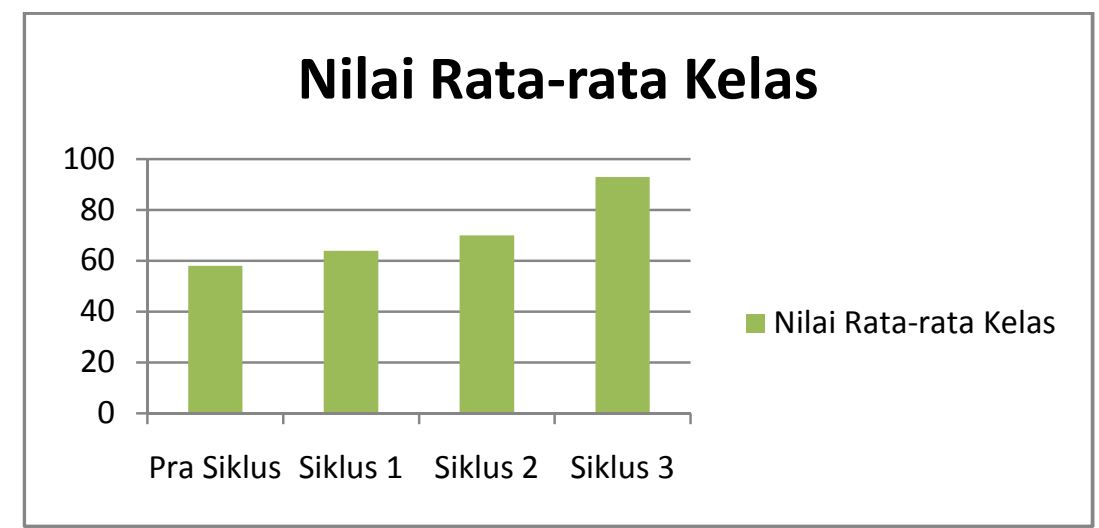

Gambar 3. Grafik Peningkatan Rata-rata Kelas

Berdasarkan grafik peningkatan nilai rata-rata kelas terdapat peningkatan yang cukup signifikan, hal itu terlihat dari rata-rata nilai kelas pra siklus sebesar 58,06 kemudian naik pada siklus 1 menjadi 64,09, kemudian naik lagi pada siklus 2 sebesar 70,15 dan siklus 3 nilai rata-rata kelas menjadi 82,69 sehingga melampaui indikator keberhasilan pada penelitian ini sebesar 75 .

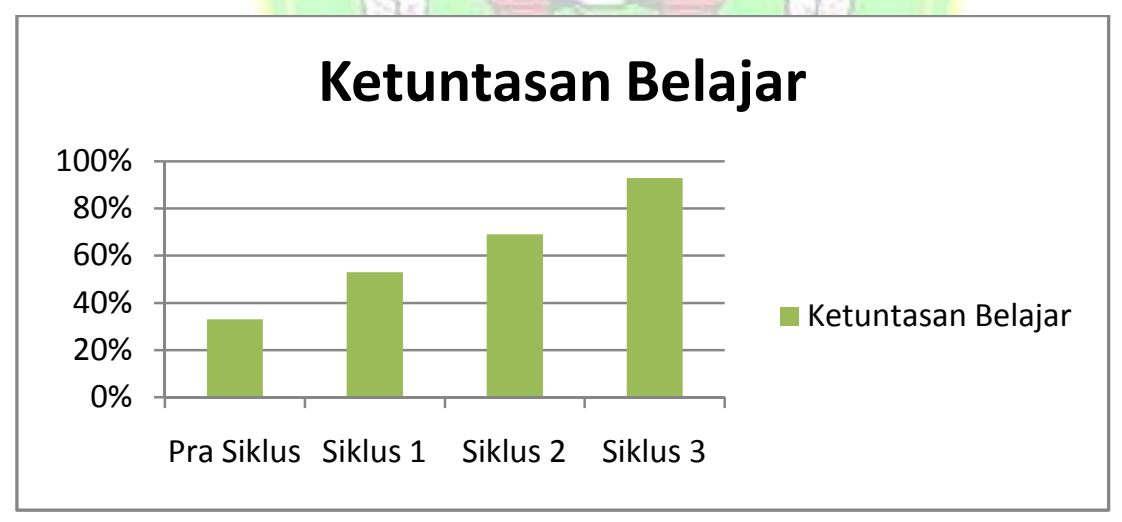

\section{Gambar 4. Grafik Peningkatan Ketuntasan Belajar}

Berdasarkan grafik ketuntasan hasil belajar siswa terdapat peningakatan disetiap siklusnya, hal itu terlihat dari ketuntasan belajar siswa yang pada pra siklus sebesar $36 \%$ atau hanya 12 siswa yang tuntas, setelah dilaksanakan tindakan siklus 1 ketuntasan belajar siswa bertambah sebanyak 5 siswa dan menjadi 20 siswa yang tuntas atau sebesar 54\%, pada siklus 2 mengalami penungkatan sebesar $69 \%$ atau 23 siswa yang tuntas dan pada siklus 3 mengalami peningkatan kembali sebesar 93\% atau 31 siswa yang tuntas 
sehingga melampaui indikator keberhasilan ketuntasan belajar siswa pada penelitian ini sebesar 75\% dari keseluruhan jumlah siswa.

4. Pembahasan

Tahap kegiatan penelitian tindakan kelas ini dilakukan meliputi perencanaan, pelaksanaan tidakan, pengamatan dan refleksi telah diperoleh data seperti di atas. Hasil data tersebut menunjukan bahwa penerapan media LKS menggunakan model pembelajaran Inkuiri mengalami peningkatan motivasi belajar siswa di kelas VIII B SMP Muhammadiyah 01 Sirampog Kab. Brebes.

Peran media LKS yang salah satunya bersifat self instruction menuntut siswa untuk belajar secara mandiri dan tidak tergantung pada pihak lain, hal ini sesuai dengan karakteristik model pembelajaran Inkuiri yang salah satunya mewajibkan setiap anggota untuk memahami materi yang dibahas dan tidak tergantung dengan anggota kelompok lain, karena sistem penilaian model pembelajaran inkuiri adalah menggunakan skor kuis individu dan berdampak pada penilaian kelompok dengan demikian setiap kelompok akan beraktivitas sangat aktif untuk memastikan semua anggotanya mengerti dan paham akan materi yang dibahas. Hal itu terbukti pada pelaksanaan tindakan meliputi siklus 1, 2 dan 3 motivasi belajar siswa mengalami peningkatan yang cukup dominan. Dari lembar pengamatan motivasi belajar siswa pada siklus 1 bahwa motivasi belajar siswa memperoleh persentase $52 \%$, siklus 2 memperoleh $72,5 \%$ dan siklus 3 memperoleh $90 \%$ dengan kategori sangat aktif.

Hasil belajar siswa sebelum penerapan media LKS menggunakan model pembelajaran inkuiri diperoleh hasil dengan nilai rata-rata kelas 58,06 dan persentase ketuntasan belajar siswa sebesar 36\% atau hanya 12 siswa yang tuntas dari 33 siswa yang mengikuti pembelajar IPS, kemudian setelah diterapkannya penerapan media LKS menggunakan model pembelajaran Inkuiri pada siklus 1 diperoleh hasil belajar dengan niali rata-rata kelas 64,09 dan persentase ketuntasan belajar 54\% atau 20 siswa tuntas dan di siklus 2 hasil belajar siswa mengalami peningkatan dengan nilai rata-rata kelas 70,15 
atau persentase ketuntasan belajar siswa sebesar 69\% atau 23 siswa telah tuntas dan pada siklus 3 memperoleh nilai rata-rata kelas sebesar 82,69 presentase ketuntasan belajar 93\% atau 31 siswa tuntas dan bagi 2 siswa yang belum tuntas peneliti melakukan remedial terhadap kedua siswa tersebut.

Hasil tersebut tidak dipungkiri bahwa peran penerapan media LKS dengan dikombinasikan model pembelajar Inkuiri dapat meningkatkan aktivitas dan hasil belajar siswa. Hal itu diperkuat juga oleh pendapat siswa bahwasannya mereka sangat menyukai diterapkannya media pembelajaran LKS, mereka sangat menantikan bahan ajar yang bersifat mandiri dan bisa dibawa pulang ke rumah,karena bisa membantu mereka dalam mengatasi kesulitan belajar apabila dalam kegiatan proses pembelajaran di kelas belum seluruhnya mengerti dan sebagai bahan belajar mereka ketika di rumah dan sebagai latihan belajar baik di kelas maupun di rumah. Mereka juga sangat termotivasi dan aktif apabila dalam pelaksanaan pembelajaran IPS menggunakan model pembelajaran Inkuiri, karena menurut mereka model pembelajaran inkuiri sangat tepat apabila dikombinasikan dengan bahan ajar, karena dimana setiap siswa berusaha untuk memahami materi yang diberikan dan terjadi interaksi yang positif antar siswa dan guru dan saling membantu untuk memahami materi.

\section{E. Kesimpulan}

Berdasarkan hasil penelitian dan pembahasan maka dapat disimpulkan bahwa:

a. Motivasi belajar siswa dalam pembelajaran IPS dikelas VIII B SMP Muhammadiyah 01 Sirampog Kab. Brebes dengan penerapan media LKS dengan menggunakan model pembelajaran Inkuiri mengalami peningkatan yang sangat aktif. Peningkatan tersebut dapat dilihat dari lembar pengamatan motivasi belajar siswa siklus 1,2 dan 3 . Pada siklus 1 diperoleh $52 \%$ dan siklus 2 diperoleh 72,5\% sedangkan siklus 3 diperoleh $90 \%$ dengan kategori sangat aktif. Motivasi belajar siswa yang sangat aktif tersebut secara langsung berkontribusi pada proses pembelajaran yang menyenangkan dan efektif. 
b. Hasil belajar siswa dalam pembelajaran IPS dikelas VIII B SMP Muhammadiyah 01 Sirampog Kab. Brebes dengan penerapan media LKS dengan menggunakan model pembelajaran Inkuiri mengalami peningkatan yang cukup efektif. Peningkatan tersebut dapat dilihat dari hasil belajar siklus 1,2 dan 3. Sebelum menerapkan bahan ajar LKS menggunakan model pembelajaran Inkuiri atau pra siklus diperoleh nilai rata-rata 58,06 dengan persentase ketuntasan belajar siswa sebesar 36\% atau hanya 12 siswa yang tuntas. Setelah dilaksanakannya siklus 1 diperoleh nilai rata-rata 64,09 dengan persentase ketuntasan belajar $54 \%$ atau 20 siswa yang tuntas, selanjutnya siklus 2 diperoleh nilai rata-rata kelas 70,15 dengan persentase 69\% atau 23 siswa tuntas dan siklus 3 diperoleh nilai rata-rata 82,69 dengan presentase $93 \%$ atau 31 siswa yang tuntas dari 33 siswa.

\section{DAFTAR PUSTAKA}

Amiruddin. 2016. Perencanaan Pembelajaran. Yogyakarta: Parama Ilmu.

Arifin, Zainal. 2009. Evaluasi Pembelajaran. Bandung: Remaja Rosdakarya.

Arikunto, Suharsini. 2015. Penelitian Tindakan Kelas. Jakarta: Bumi Aksara

Aqib, Zainal. 2014. Penelitian Tindakan Kelas. Bandung: Yrama Widya.

Azhar, L. 1993. Proses Belajar Mengajar Pola CBSA. Usaha Nasional : Surabaya.

Balitbang Depdiknas. 2002. Penilaian Berbasis Kelas. Jakarta: Depdikbud.

Burhan Bungin.2005. Analisisi Data Penelitian Kualitatif. Jakarta: Raja Grafindo Persada.

Komalasari, Kokom. 2011. Pembelajaran Kontekstual, Konsep Dan Aplikasi, Kualitatif, Dan $R \&$ D. Alfabeta: Bandung. $321 \mathrm{Hlm}$.

Kusnandar, 2008. Penelitian Tindakan Kelas. Jakarta : Raja Grafindo Persada.

Madjid, A. 2007. Perencanaan Pembelajaran (Mengembangkan Standar Kompetensi Guru). Remaja Rosdakarya : Bandung.

Rusman. 2012. Model-model Pembelajaran Pengembangan Profesionalisme Guru. Jakarta: Grafindo Persada. 
Sanjaya, Wina. 2010, Strategi Pembelajaran Berorientasi. Standar Proses Pendidikan. Kencana Premada Media Group: Jakarta. 208 Hlm.

Sapriya. 2009. Pendidikan IPS. Jakarta: Remaja Rosdakarya.

Sardiman.1986. Interaksi dan Motivasi Belajar Mengajar. Jakarta: Rajawali.

Soemantri, Muhammad Numan. 2001. Menggagas Pembaharuan Pendidikan IPS. Bandung: Remaja Rosdakarya.

Sumiati dan Asra. 2008. Metode Pembelajaran. Bandung: Wacana Prima.

Sutikno. M. Sobry. 2008. Belajar dan Pembelajaran Upaya Kreatif dalam Mewujudkan Pembelajaran yang Berhasil. Bandung: Prospect.

Suwarno, Jonathan. 2006. Metode Penelitian Kualitatif Dan Kuantitatif. Yogyakarta: Graha Ilmu.

Sugiyono. 2010. Metode Penelitian Pendidikan Pendekatan Kuantitatif, Kualitatif, dan $R \& D$. Bandung: Alfabeta.

Uno, B. Hamzah. Model Pembelajaran. BumiAksara; Jakarta.

Wiria atmadja, Rochiati. 2008. Metodologi Penelitian Tindakan Kelas. Remaja Rosda karya; Bandung. 